Geçgel, H., Kana, F. ve Eren, D. (2020). Türkçe eğitiminde dijital yetkinlik kavramının farklı değişkenler açısından incelenmesi. Ana Dili Ĕ̆itimi Dergisi, 8(3), 886-904.

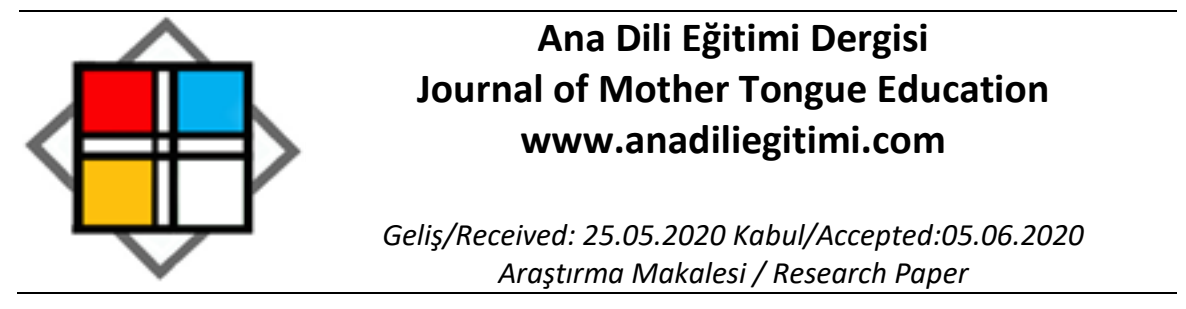

\title{
Türkçe Eğitiminde Dijital Yetkinlik Kavramının Farklı Değişkenler Açısından İncelenmesi*
}

\author{
Hulusi GEÇGEL ** \\ Fatih KANA ${ }^{* * *}$ \\ Duygu $E R E N^{* * * *}$
}

\begin{abstract}
Öz
Dünyada ve Türkiye'de devam eden COViD 19 salgını süresince araştıran, düşünen, üreten bireyin yanı sıra dijital yetkinliğe sahip bireylerin önemi ortaya çıkmıştır. Özellikle öğrencilerin okula gidememesi ve derslerin uzaktan yapılması süresince, teknolojik donanım eksikliği, içerik eksikliği ve bireylerin dijital yetkinlik eksikliği ön plana çıkmıştır. Bu çalışmanın amacı ortaokul öğrencilerinin dijital yetkinlik becerileriyle ilgili öğretmen görüşlerini belirlemektir. Bu amaç doğrultusunda araştırmada nitel araştırma yöntemlerinden durum çalışması deseni kullanılmıştır. Araştırmanın çalışma grubunu Türkiye'nin batısında yer alan bir devlet ortaokulunda görev yapan öğretmenler oluşturmaktadır. Araştırmanın veri analizinde içerik analizi yöntemi kullanılmıştır. Araştırmada veri toplama aracı olarak yarı yapılandırılmış görüşme formu kullanılmıştır. Okullarda FATiH projesinden dolayı etkileşimli tahtaların yeteri kadar bulunduğu ama bilgisayarların ihtiyacı karşılayacak düzeyde ve dijital çağa uygun olmadığı görülmüştür. Öğrencilerin proje merkezli değil de sınav merkezli yetiştiği, bu yüzden teknolojik araçlara yönelmede problem yaşandığ görülmüştür. Dünyayı etkisine alan COVID 19 salgını sürecinde öğretmen ve öğrencilerin dijital yetkinlikler açısından yetiştirilmesi gerektiği görülmüştür. Bu araştırmada dijital yetkinlik açısından öğretmenlerin, öğrencilerin, programların ve kitapların yeniden değerlendirilmesi gerektiği sonucuna ulaşılmıştır.
\end{abstract}

Anahtar Sözcükler: Dijital Yetkinlik, dijital öğrenme, EBA, FATiH projesi, COVID 19.

\section{Investigation of the Concept of Digital Competence in Terms of Different Variables in Turkish Education}

\begin{abstract}
During the ongoing COVID 19 epidemic in the world and Turkey who produces as well as the importance of individuals it has emerged with the digital competence of individuals. Especially during the students 'not being able to go to school and the lessons being done remotely, the lack of technological equipment, the lack of content and the individuals' digital competence came to the fore. The aim of this study is to determine teachers' opinions about digital competence skills of secondary school students. For this purpose, a case study pattern, one of the qualitative research methods, was used in the research. Working group of the research is located west of Turkey are working in a state secondary school teachers. Content analysis method was used in the data analysis of the research. In the research, semi-structured interview form was used as a
\end{abstract}

\footnotetext{
* Çanakkale Onsekiz Mart Üniversitesi Sosyal Bilimler ve Eğitim Bilimleri Etik Kurulu 16.04.2020 tarih 03 nolu karar. Protokol Numarası: 2020/58

** Dr. Öğretim Üyesi, Çanakkale Onsekiz Mart Üniversitesi, Eğitim Fakültesi, Türkçe ve Sosyal Bilimler Eğitimi Bölümü, Çanakkale, hgecgel@comu.edu.tr ORCID ID: https://orcid.org/0000-0002-9277-6417

${ }^{* * *}$ Dr. Öğretim Üyesi, Çanakkale Onsekiz Mart Üniversitesi, Eğitim Fakültesi, Türkçe ve Sosyal Bilimler Eğitimi Bölümü, fatihkana@hotmail.com ORCID ID: https://orcid.org/0000-0002-1087-4081

**** Yüksek Lisans Öğrencisi, Çanakkale Onsekiz Mart Üniversitesi, Eğitim Bilimleri Enstitüsü, Türkçe ve Sosyal Bilimler Eğitimi Anabilim Dalı, Çanakkale, gunef_duygu@hotmail.com, ORCID: orcid.org/0000-0002-3751-0720
} 
data collection tool. It has been observed that interactive boards are sufficient in schools due to the FATIH project, but computers are not at a level to meet the needs and are not suitable for the digital age. It was seen that the students grew up in the exam center rather than the project center, so there was a problem in turning to technological tools. When the results of this research are examined, it was concluded that teachers and students should be trained in terms of digital competencies during the COVID 19 outbreak process.

Keywords: Digital Competence, digital learning, EBA, FATIH project, COVID 19

\section{Giriş}

21. yüzyılda bireylerin ilerleyebilmesi için kendini geliştirmeye ihtiyaçları vardır. Günümüz ihtiyaçları göz önüne alındığında bilgiyi doğrudan alıp kullanmanın yeterli olmadığı görülmektedir. Bilgiye doğru kaynaklardan ulaşma, bilginin güvenirliğini sorgulama, elde edilen bilgiyi yorumlayarak işlevsel hale getirme ve günlük hayata transfer edebilme kabiliyeti son derece önem kazanmıştır (Fraillon, Ainley, Schulz, Friedman ve Gebhardt, 2014). İşlevsel olmayan ve transfer edilemeyen bilginin etkililiğinden söz edilemez. Bu yüzyılda bilginin etkililiğini artırabilmek için teknolojiye hâkim olmak gerekmektedir.

Bilgi çağı olarak adlandırılan bu yüzyılda, insanlar bilgiyi daha çok internet, bilgisayar ve mobil kaynaklardan öğrenmektedir. 2020 yılı Global Dijital Raporu'na göre, dünyada internet kullanıcı sayısı 4.54 milyara yükselmiştir. Dünya çapında 3.80 milyar sosyal medya kullanıcısı bulunmakta, 5.19 milyardan fazla kişi cep telefonu kullanmaktadır. Ortalama bir internet kullanıcısı her gün çevrimiçi olarak 6 saat 43 dakika internet kullanmaktadır (Fundalina, 2020). Bütün bu veriler dikkate alındığında 2025 yılında dünya üzerinde 8 milyar insanın internet erişimine sahip olması beklenmekte ve bu sayının katlanarak artacağı tahmin edilmektedir (Schmidt ve Cohen, 2013, s.4).

Dünya çapında birçok sivil toplum kuruluşu (Avrupa Birliği, ATCS, OECD) 21. yüzyılda bireylerin sahip olması gereken becerileri kendi ölçütlerini ve yüzyılın ihtiyaçlarını dikkate alarak belirlemişlerdir. Bu beceriler eleştirel ve yaratıcı düşünme, problem çözme, teknolojik araçları kullanabilme gibi üst düzey becerilerdir (Kazikoğlu ve Altunova, 2018, s.523). Bireyler, bu becerileri etkin bir şekilde kullanabilirse yeni teknolojik dünyaya ayak uydurabilirler.

Bilim ve teknolojideki gelişmeler, eğitimde ihtiyacı çeşitlendirmekle beraber eğitim ortamı ve içeriklerini de etkilemektedir. Günümüzde eğitim ortamları kısmen de olsa sanal ortamlara, dijital platformlara taşınmış durumdadır (Şirin, 2016, s. 24). Borich (2017), iyi planlanmayan bir öğretimi teknolojik araçların iyileştiremeyeceğini ifade etmektedir. Endüstri 4.0 sürecine uyum sağlamak amacıyla eğitimcilere dijital yetkinlik kazandırılması ve bu yetkinliklere sahip işgücünün sanayi ile buluşturulması hedeflenmektedir (Doğru ve Meçik, 2018). Bütün bu gelişmeler dikkate alındığında bilgiyi yorumlayabilmenin, etkili ve etkin kullanabilmenin önemi ortaya çıkmaktadır (Kazu ve Erten, 2014, 133).

Fırsatları Artırma ve Teknolojiyi İyileştirme Hareketi Projesi, kısa adıyla "FATiH" projesi, 2010 yılından beri eğitimde uygulanmaktadır. Bu projenin hedefi teknolojiyi eğitime transfer ederek çağın yeterliklerine uygun bireyler yetiştirmektir. Bu proje kapsamında okul öncesinden başlayarak 570 bine yakın sınıfı etkileşimli tahtalarla buluşturmayı hedefleyen proje, bilişim teknolojileri (BT) tabanlı e-içeriklerin oluşturulmasını ve bu süreçte aktif rol oynayacak eğitimcilerin hizmet içi eğitimlerle yetiştirilmesini amaçlamıştır (MEB, 2014'ten akt. Eryılmaz ve Uluyol, 2015, s.221). FATiH projesinin alt yapısını Yenilik ve Eğitim Teknolojileri Genel Müdürlüğü tarafından tasarlanan Eğitim Bilişim Ağı (EBA) Projesi oluşturmaktadır (EBA, 2014'ten akt. Eryılmaz ve Uluyol, 2015, s. 221). EBA projesinin eğitimde etkililiği ile ilgili birçok araştırma yapılmıştır (Bahçeci ve Efe, 2018; Demir, Özdinç ve Ünal, 2018; Arslan ve Kuzu, 2019). Bu araştırmalarda EBA'nın etkili olup olmadığı tartışılırken 2019'da başlayan ve bütün dünyayı etkisi altına alan COViD 19 salgını nedeniyle EBA; okul öncesinden, liseye uzaktan eğitim programları başlatmış, EBA TV kurulmuş ve proje bir anda geliştirilmeye başlanmıştır.

FATiH projesi teknolojiyi eğitimle birleştiren, 21. yüzyıl ihtiyaçlarına cevap veren bireyler yetiştirme konusunda önemli bir adım olmuştur. Ancak topluma, kültürüne katkı sağlayan, onu eleştiren, sorgulayan, doğru bilgiye ulaşma yollarını bilen, medya okuryazarı olabilmiş ve bilgisini yaratıcılığı ile harmanlayıp işlevsel hale getirebilmeyi başarmış bireyleri bir anda yetiştirebilmek kolay 
değildir. Dijital yüzyıl olarak adlandırabilecek olan bu çağda, öğretmen ve öğrenci rolleri de farkı bir boyut kazanmıştır. Teknolojinin içerisinde doğan, teknolojiyi günlük hayatın her alanında kullanabilen dijital yerliler olarak adlandırılan 21. yüzyıl çocuklarının etrafı sanal bir bilgi ağıyla çevrelenmiştir. Dijital yerliler, değişen dünya düzenine kolayca uyum sağlayabilmekte ve bu düzende etkin bir rol almaktadırlar. İnternette yer alan sınırsız bilgi içerisinde dijital yerlilerin kaybolmaması için bilgiyi nasıl bulacaklarını, nasıl kullanacaklarını, dijital yetkinlik düzeylerini nasıl arttırabileceklerini onlara öğretmek gerekmektedir. Bu süreçte dijital göçmen olan eğitimcilerle, dijital yerlilerin iyi bir etkileşim içerisine girmeleri gerekmektedir (Bilgiç, Duman ve Seferoğlu, 2011). Dijital yerli öğrenciler teknolojiyi amaç değil, araç olarak kullanmayı öğrendiğinde; dijital göçmen eğitimciler de çağın gereklerine uygun, etkileşimli, e-içeriklerle zenginleştirilmiş ders metotlarını öğrendiğinde iki kuşak arasında köprü kurulmuş ve verimli bir eğitim ortamı sağlanmış olacaktır.

Günümüzde dijital göçmen olarak adlandırabilecek ailelere ve eğitimcilere çeşitli seminer programları ve destekleme-yetiştirme kurslarıyla yol göstermek, onların teknoloji dilini daha iyi anlamalarını sağlayacak, böylece yeni nesil ile güçlü bir iletişim kurma hedefinde önemli atılımlar gerçekleşmiş olacaktır. Böylece dijital yerlilerin yani geleceği şekillendirecek neslin bilinçli ve tecrübeli eğitimciler ve aile bireyleri rehberliğinde dijital yetkinliğe ulaşmalarını, teknoloji ile daha sağlıklı bir iletişim kurmalarını sağlanabilecektir. Tüm bu gelişmeleri sağlarken eğitim düzeyi gelişmiş ülkelerin ortak politikası olan hayat boyu öğrenme kavramı üzerinde durulması gerekmektedir. Hayat boyu öğrenmeyi aktif kılacak, eğitim ve iş gücünü ileri düzeye taşıyabilecek bir sistem oluşturulması için Avrupa Yeterlilikler Çerçevesi ile bağlantılı Türkiye Yeterlilikler Çerçevesi (TYÇ) meydana getirilmiştir. TYÇ'nin genel hedefi, yeterliliklerin tespit edilip ifade edilmesi, daha sonra bunların sınıflandırılıp yeterlilikler arasındaki bağlantı ve ilişkilerin ortaya çıkarıldığı bütünsel bir oluşum sunulmasıdır (https://www.myk.gov.tr/index.php/tr/turkiye-yeterlilikler-cercevesi).

Yenilenen Türkçe Dersi Öğretim Programı'nda öğrencilerin hem ulusal hem de uluslararası düzeyde intiyaç duyacakları yetkinlikler TYÇ'de belirlenmiştir. Öğrencilerin yetkinlikleri hayat boyu kullanabilecek beceri ve davranışlara dönüştürebilmeleri için anadilde iletişim, yabancı dillerde iletişim, matematiksel yetkinlik ve bilim/teknolojide temel yetkinlikler, dijital yetkinlik, öğrenmeyi öğrenme, sosyal ve vatandaşlıkla ilgili yetkinlikler, insiyatif alma ve girişimcilik, kültürel farkındalık ve ifade olmak üzere sekiz anahtar yetkinlik belirlenmiştir (MEB, 2019). Bu çalışmada anahtar yetkinlikler içerisinde yer alan "Dijital Yetkinlik" kavramı üzerinde durulmuştur. Teknolojik becerilere ilişkin ortaya çıkan en yeni kavramlardan biri ise dijital yetkinlik kavramıdır (Ilomäki, Kantosalo ve Lakkala, 2016, s.1). Dijital yetkinlik, "bilgisayar aracilığı ile farklı kaynaklardan çeşitli formatlarda sunulan bilgiyi anlama ve kullanma becerisi" olarak ifade edilmiştir (Knobel ve Lankshear, 2008; Akt. Larraz ve Esteve, 2015). Dijital yetkinlik; bilgi iletişim teknolojilerinin güvenli ve eleştirel biçimde kullanılmasını sağlamaktadır. Bu yetkinlik alanında bilgiye erişim ve bilginin değerlendirilmesi, saklanması, üretimi, sunulması ve alışverişi için bilgisayarların kullanılması, ayrıca internet aracılığıyla ortak ağlara katılım sağlanması ve iletişim kurulması temel beceriler yoluyla desteklenmektedir (MEB, 2019, s. 5). Kurudayıoğlu ve Soysal (2020) tarafından yapılan araştırmada Türkçe Dersi Öğretim Programı'nda yer alan dijital yetkinlik kazanımlarının belirli alanlarda yoğunlaştığı, konuşma ve yazma alanlarında dijital yetkinlikle ilgili kazanımlara daha az yer verildiği görülmüştür.

\section{Araştırmanın Amacı}

Türkçe Dersi Öğretim Programında yer alan dijital yetkinlik, eğitim ortamlarına doğru yansıtıldığında 21. yüzyıl becerilerini bünyesinde barındıran, çağın gerektirdiği atılımları yapmayı başaracak donanımda ve yorumlama kabiliyeti yüksek bireyler yetiştirmek mümkün olacaktır. Bu çalışmanın amacı öğretmen gözüyle öğretim programlarını, ders kitaplarını ve öğrencilerin dijital yetkinlik durumlarını tespit etmektir. Türkçe eğitiminde dijital yetkinlik kavramının farklı değişkenler açısından incelenmesi amacıyla aşağıda belirtilen sorulara cevap aranmıştır:

1. Okuldaki teknolojik araçların yeterliliği nasıldır?

2. Teknoloji konusunda okulun fizikî yapısındaki sınırlııkların öğretim programına uygun hareket etmeye etkisi nedir? 
3. Öğrencilerin okulda proje ya da araştırma yapmak için teknolojik araçlara yönelme sıklığı nasıldır?

4. Güncellenen Türkçe Dersi Öğretim Programıyla eski programlar arasında dijital yetkinlik açısından farklılıklar nelerdir?

5. Yapılandırmacı yaklaşımın öğrencilerde dijital yetkinlikleri geliştirme düzeyine katkıları nelerdir?

6. Türkçe dersi çalışma kitaplarındaki etkinliklerin dijital yetkinlikle ilgili kazanımları yansıtabilme durumu nasıldır?

7. Öğrencilerin blog, e-posta gibi dijital okuryazarlık becerisi gerektiren metin türleriyle ilgili tutumu nasıldır?

8. Bilim ve teknoloji temasının dijital yetkinlik düzeyini geliştirmeye etkisi nasıldır?

9. Öğrencilerin verilen projelerle ilgili araştırma yaparken gerekli bilgileri diğerlerinden ayırma, kaynağı sorgulama ve bulguları yorumlama düzeyi nasıldır?

10. MEB seminerlerinin teknoloji, eğitim ve dijital yetkinlik konusuna değinme durumu nasıldır?

11. Öğretmenlerin derslerinde teknolojiyi eğitime transfer edebilmek için yaptıkları çalışmalar nelerdir?

12. Öğretmenlerin dijital yetkinlik kavramıyla ilgili görüşleri nelerdir?

\section{Araştırmanın Modeli}

\section{Yöntem}

Araştırmada nitel araştırma desenlerinden durum çalışması deseni kullanılmıştır. Durum çalışması, nasıl ve neden sorularına cevap arayan, derinlemesine zengin bir veri toplama olanağı sağlayan bir araştırma desenidir. Durum çalışması karmaşık bir olayı anlama çabasıdır. Durum çalışmasının temel yapıtaşı güncel olay, gerçek dünya bağlamı ve derinlemesine incelemedir Akar, 2016, s. 113-120). Bu araştırmada ortaokul öğrencilerinin dijital yetkinlik beceri düzeylerini belirleyebilmek için durum çalışması deseni kullanıımıştır. Araştırmanın konusu olan dijital yetkinlik dünya çapında ortaya çıkan COVID 19 salgınından dolayı hem güncel hem de gerçek dünya bağlamında bir konudur. Öğrenciler bu süreçte okula gitmedikleri için uzaktan eğitim yoluyla derslerine girmektedir. Öğrencilerin bu dersleri dinleyebilmeleri ve tepki verebilmeleri için hem dijital araçlara hem de dijital becerilere sahip olmaları gerekmektedir. Bunun yanı sıra ders kitaplarının, öğretim programlarının ve öğretmenlerin de dijital yetkinlik yeterliğine sahip olmaları gerekmektedir.

\section{Örneklem / Araştırma grubu}

Araştırmanın çalışma grubunu Türkiye'nin batısında yer alan bir devlet ortaokulunda görev yapan öğretmenler ve okul müdürü oluşturmaktadır. Okul müdürü, bir bilişim teknolojileri öğretmeni ve beş Türkçe öğretmeni ile röportaj yapılarak yarı yapılandırılmış görüşme formuyla detaylı bir şekilde kişilerin görüşleri alınmıştır. Okul müdürüne okulun fizikî durumu başlığı altında toplam 5 açık uçlu soru; öğretmenlere ise öğretim programları ve ders kitapları konu başlıklı 6, öğretmen fikirleri konu başlıklı 7 olmak üzere toplamda 13 açık uçlu soru yöneltilmiştir. Araştırma içerisinde yer alan öğretmenler kodlanarak araştırmada yer almıştır. Araştırmanın çalışma grubunda yer alan Ö1 kodlu okul müdürü 47 yaşında ve 5 yıldır okulda yöneticilik yapmakta; Ö2 kodlu Türkçe öğretmeni 49 yaşında, 24 yıldır Türkçe öğretmenliği yapmakta; Ö3 kodlu Bilişim Teknolojileri öğretmeni 35 yaşında, 10 yıldır Bilişim Teknolojileri öğretmenliği yapmakta; Ö4 kodlu Türkçe öğretmeni 38 yaşında ve 15 senedir Türkçe öğretmenliği yapmakta; Ö5 kodlu Türkçe öğretmeni 35 yaşında, 12 yıldır Türkçe öğretmenliği yapmakta; Ö6 kodlu Türkçe öğretmeni 33 yaşında, 10 yıldır Türkçe öğretmenliği yapmakta ve Ö7 kodlu Türkçe öğretmeni 35 yaşında, 12 yıldır Türkçe öğretmenliği yapmaktadır.

\section{Veri Toplama Araçları}

Araştırmada araştırmacı tarafından oluşturulan yarı yapılandırılmış görüşme formu kullanılmıştır. Yarı yapılandırıımış görüşme formunda öğrencilerin dijital yetkinlikleri kazanması süreciyle ilgili öğretmenlerin değerlendirmelerini içeren sorular yer almıştır. Form hazırlanırken 
araştırmacılar tarafından alan yazın taraması yapılmıştır. Alan yazın taraması sonucunda öğrencilerin dijital yetkinlik süreçlerini farklı bakış açılarıyla incelemek amacıyla bir soru havuzu oluşturulmuştur. Formun nitel araştırmaya uygunluğunu değerlendirmek üzere alanında uzman öğretim üyelerinden soruların çalışma için uygun olup olmadığına dair görüşler alınmıştır. Bu görüşler doğrultusunda araştırmada kullanılacak forma son hali verilmiştir. Formda kullanılacak soruların anlaşılırlığını tespit etmek amacıyla bir pilot uygulama yapılmıştır. Pilot uygulama sonrasında son düzeltmeler yapılarak form araştırmanın çalışma grubuna uygulanmıştır. Form, çalışma grubuna yüz yüze uygulanmıs olup, ses kayıt cihazı yardımıyla kayıt altına alınmıştır.

\section{Verilerin Analizi}

Araştırmadan elde edilen veriler nitel veri analiz yöntemlerinden betimsel analiz yoluyla analiz edilmiştir. Betimsel analizde veriler, araştırmacı tarafından önceden belirlenen temalara göre yorumlanır (Yıldırım ve Şimşek, 2018). Araştırmadan elde edilen veriler araştırmacı tarafından önceden belirlenen temalara göre analiz edilmiştir. Ayrıca araştırmadan elde edilen verilerin inandırıcılığını arttırmak amacıyla çalışma grubundan elde edilen doğrudan aktarma yoluyla çalışmada yer almıştır. Araştırma katılanlara araştırmacı tarafından kod verilmiştir (Ö1, Ö2, Ö3...). Veri analizinin güvenirliğini sağlamak amacıyla araştırmaya ikinci bir kodlayıcı daha katılmıştır. Miles ve Huberman (2015, s. 64) tarafından geliştirilen güvenirlik formülü (Güvenirlik=Görüş birliği sayısı / (Toplam görüş birliği + Görüş ayrılı̆ı sayısı) araştırmada uygulanmıştır. Yapılan analize göre, güvenirlik katsayısı=.87 olarak hesaplanmıştır. Araştırmada elde edilen bu bulgu araştırmadan elde edilen kodlamaların güvenilir olduğunun göstergesidir.

\section{Geçerlik ve Güvenirlik}

Araştırmanın yapısal geçerliğini sağlamak için katılımcı çeşitlemesi yapılmıştır. Araştırmada veri toplanan katılımcıların sadece tek branştan değil; farklı branş, yaş grubu ve hizmet yılına sahip öğretmenlerden oluşmasına dikkat edilmiştir. Araştırmada elde edilen veriler farklı araştırmacılar tarafından analiz edilerek bulguların ve analizlerin birbiriyle tutarlı olması sağlanmıştır. Araştırmanın iç geçerliğini sağlamak için araştırmanın çalışma grubundan aynen alıntılar yoluyla elde edilen veriler bulgular bölümünde yer almıştır. Araştırmanın bulguları genellenerek dış geçerlik sağlanmıştır. Araştırmanın iç güvenirliğini sağlamak amacıyla başka araştırmacıların verileri incelemesi ve doğrulaması sağlanmıştır (Creswell, 2013; Merriam, 2013).

\section{Etik Kurulu İzni}

Araştırmanın etik kurulu izni, Çanakkale Onsekiz Mart Üniversitesi Sosyal Bilimler ve Eğitim Bilimleri Etik Kurulu 16.04.2020 tarih 03 nolu kararıyla alınmıştır. Ayrıca araştırmaya katılanlar araştırmaya gönüllü olarak katılıklarını beyan etmişlerdir.

\section{Bulgular}

Araştırmanın bu bölümünde öğretmenlerin ortaokul öğrencilerinin dijital yetkinlikleriyle ilgili görüşleri incelenmiştir.

Tablo 1.

Okuldaki Teknolojik Araçların Yeterliliği ile ilgili Öğretmen Görüşleri

\begin{tabular}{lc}
\hline Kodlar & $(\mathrm{f})$ \\
\hline İhtiyacı karşılayacak düzeyde değil & 3 \\
Dijital çağa uygun değil & 2 \\
\hline
\end{tabular}

Tablo 1 incelendiğinde okullarda etkileşimli tahtaların yeterli olduğu, okulda var olan bilgisayarların dijital çağa uygun olmadığı, donanım olarak yetersiz olduğu öğretmenler tarafından vurgulanmıştır. Konuyla ilgili öğretmen görüşleri şu şekildedir:

Ö3 kodlu katılımcı "Etkileşimli tahtaların akıbeti uzun süreli olmayacak, sürekli arızalanıyor. Okul bilgisayarlarının da eski ve işlevsiz olduğunu düşünüyorum." 
Ö2 kodlu katılımcı "Bilgisayarlar yeterli sayılmaz, eksiklerimiz var."

Ö1 kodlu katılımcı "Etkileşimli tahtalar yeterli ama bilgisayarlar öğrenciler için yeterli değil."

Tablo 2.

Teknoloji Konusunda Okulun Fizikî Yapısındaki Sınırlılıkların Öğretim Programına Uygun Hareket Etmeye Etkisi ile ilgili Öğretmen Görüşleri

\begin{tabular}{lc}
\hline Kodlar & $(\mathrm{f})$ \\
\hline İnternet sınırlı & 4 \\
Internetteki erişim engeli & 4 \\
Bina yeterli değil & 3 \\
Bilgisayarlar eski & 2 \\
Akıllı tahtalar eğitimi olumsuz etkiliyor & 1 \\
\hline
\end{tabular}

Araştırmaya katılan öğretmenler okul binasının teknolojik bir alan oluşturmak için yeterli olmadığını, akıllı tahtaların öğretimi aksattığını, okullarda bilgisayarlarda güncelleme ve internet bağlantısı sorunu yaşadıklarını, Millî Eğitim Bakanlığı tarafından internet sınırlandırıldığı için EBA'nın etkin kullanılmadığını, erişim engelinden dolayı dinleme metinlerinde youtube vb. kanallardan yararlanamadıklarını ifade etmektedirler. Bu konuyla ilgili öğretmenlerin görüşleri şu şekildedir:

Ö3 kodlu katılımcı: "Okul içinde akıllı tahtaları kullanabilirler ama onun dışında bilgisayarları kullanamıyorlar çünkü sağııkı bir internet bağlantımız da yok. Dediğim gibi bilgisayarlar zaten bozuk, o yüzden kullanamıyorlar."

Ö2 kodlu katılımcı: "MEB interneti olduğu için bazı şeylere ulaşmakta sıkıntı çekiyoruz. Sınırlandırma getiriyor. EBA'yı rahatça kullanabiliyoruz fakat farklı sitelere yönelemiyoruz. Mesela Türkçe dinleme metinlerini video içeriği olan sitelere girip açamıyoruz. Bence bu sınırlandırma biraz genişletilmeli, öğrencilerin olumsuz içeriklere yönelmesi bir şekilde önlenebilir. Ben bilgiye ulaşımın daha kolay olması gerektiğine inanıyorum. Bunun eksikliğini derslerimde hissediyorum."

Ö7 kodlu katılımcı: "Derste dinleme metinlerini pratik bir şekilde açıp dinletmek mümkün değil, youtube gibi uygulamalara erişim engelimiz var. Ben öğrenciye o an aklıma gelen konuyla ilgili bir kısa film ya da video izletmek istiyorum ama mümkün olmuyor."

Ö4 kodlu katılımcı: "Dinleme metinleri bize cd olarak gelmiyor. Mesela 5. sınıfların kitabında yer alan dinleme metinleri elimizde hiç yok. Bulamadığımı için başka konularla geçiştirdik."

Tablo 3.

Öğrencilerin Okulda Proje ya da Araştırma Yapmak Için Teknolojik Araçlara Yönelme Sıklı̆̆ı Hakkında Öğretmen Görüşleri

\begin{tabular}{lc}
\hline Kodlar & $(\mathrm{f})$ \\
\hline Sinav & 1 \\
Hevesli değiller & 2 \\
\hline
\end{tabular}

Araştırmanın katılımcılarının okulda proje ya da araştırma yapmak için teknolojik araçlara yönelme yerine sınav hazırlıkları olduğu için daha çok test çözmeye yöneldikleri görülmektedir. Katılımcılar, öğrencilerin proje ve araştırma yapmak için teknolojiyi nadiren kullandıklarını ama bu konuda hevesli olmadıklarını ifade etmektedirler.

Tablo 4.

Güncellenen Türkçe Dersi Öğretim Programıla Eski Programlar Arasındaki Farklılıklarla Ilgili Öğretmen Görüşleri

\begin{tabular}{lc}
\hline Kodlar & (f) \\
\hline Dil bilgisi konuları & 4 \\
Anlatım bozuklukları & 4 \\
Okuduğunu anlamaya ve yorumlama & 3
\end{tabular}


Fiil çatıları

Üst düzey beceriler

Öğretim programları çağın ihtiyaçlarına göre yenilenmektedir. Öğretmenler yenilenen bu programlarda dil bilgisi konularının sadeleştirildiğini, ortaokul düzeyinde okuduğunu anlama ve yorumla üzerinde durmanın etkili olabileceğini, anlatım bozukluklarının basit düzeyde işlendiğini ve 7., 8. sınıfa paylaştırılıı̆ını; fiil çatılarıyla ilgili önceden detaylı bir anlatım olurken yenilenen programlarda bunun yüzeysel kaldığını, programda anlama becerisi, yorumlama, karşılaştırma becerilerinin ön planda olduğunu ve sınavlarda çıktığını; EBA uygularken çocukların işitsel ve görsel zekâlarına hitap etmenin önemli olduğunu ifade etmişlerdir. Programlarda dil bilgisi sadeleştirilerek PISA tarzı sorulara önem verilmiş, mantık ve yorum gücüyle bilgiye ulaşmanın önemi üzerinde durulmuştur. Bireyler 21. yüzyılda bilgiye her yerden ulaşabilir; teknoloji, bizlere bu imkânı sunmaktadır. Önemli olan bireylerin yorumlama ve sorgulama becerileriyle beraber bilgileri günümüz ihtiyaçlarını karşılayacak şekilde işlevsel hale getirmeleridir. Bunun için de ortaokul programlarında okuduğunu anlama ve yorumlama becerisinin üzerinde durulması iyi bir başlangıç olacaktır. Bu konu hakkındaki öğretmen görüşleri şu şekildedir:

Ö6 kodlu katılımcı: "Dil bilgisi konuları artık daha yüzeysel, öğrencileri fazla zorlamıyor. Öyle de olmalı zaten. Ortaokul düzeyindeki öğrencilerde okuduğunu anlama ve yorumlamaya ağırlık verilmesini doğru buluyorum. Teknoloji ile ilgili de EBA'dan destek almak güzel. Görsel ve işitsel zekâya sahip öğrencileri derse daha çok yönlendirebiliyoruz."

Ö7 kodlu katılımcı: "Birkaç dil bilgisi konusunun hafifleştirildiğini gördük. 8.Sınıf zaten sınava hazırlık olarak yoğun ve yorucu geçiyordu. Biraz konuların hafifletildiğini gördük. Anlama becerisi, yorumlama, değerlendirme, karşılaştırma becerilerinin ön plana çıktığını gördük ve bunların sınavda olması nedeniyle bu şekildeki çalışmaları biz de yapıyoruz."

Ö5 kodlu katılımcı: "SSimdiki kitaplarda anlama, anlatım, anlam bilgisi daha ağırıklı. Kesinlikle daha faydalı olduğunu düşünüyorum. Dil bilgisinde de sadece anlatım bozukluklarını ayırmışlar 7 ve 8.sınıf olarak. Konunun bir kısmını 7. sınıfa kaydırmışlar. Bu da onlar için daha iyi oldu."

Tablo 5.

Yapılandırmacı Yaklaşımın Öğrencilerde Dijital Yetkinlikleri Geliştirme Düzeyine Katkıları Ile Ilgili Öğretmen Görüşleri

\begin{tabular}{lc}
\hline Kodlar & (f) \\
\hline Araştırıp öğrenme & 2 \\
Yeni nesil öğrencilere uygun & 2 \\
Ödev ve uygulama & 1 \\
Sunum yapmaya istekli çocuklarda & 1 \\
\hline
\end{tabular}

Öğretmenler, çocuklar kendileri araştırıp öğrendikleri için özgüvene bağlı olarak yapılandırmacı eğitim anlayışının etkili olduğunu, yapılandırmacı yaklaşımın teknoloji çağında doğan çocuklar için iyi bir yaklaşım olduğunu, proje odaklı yaklaşımlarda, sunum yapmaya hevesli çocuklara etkisi olduğunu belirtmektedirler. Öğretmenler genel olarak, yapılandırmacı yaklaşımın dijital yetkinlikleri geliştirme düzeyine olumlu etki yaptığını belirtmiştir. Bazı katılımcılar Dijital Yerli olarak adlandırılan yani teknolojinin içinde doğan ve onunla büyüyen çocukların kuşak olarak yetişkinlerden farklı dünya görüşlerine ve bakış açılarına sahip olduklarını ifade etmiştir. Çocuklarda düşünme ve muhakeme becerilerinin 21. yüzyıl dünyasının isteklerine cevap vermede yetişkinlere göre, özellikle 50-60 yaş civarı öğretmenlere göre, daha başarılı olduğu görülmektedir. Dijital çağın çocukları bilgiyi işlemede daha pratik olduklarından yapılandırmacı yaklaşımla bilgiye kendilerinin ulaşmalarının, öznel bilgi oluşturup yorumlamaya açık hale getirmelerinin onların doğasına daha uygun olduğu görülmektedir. Bir katılımcı da görüşmede yapılandırmacı yaklaşımın öğrencilere sorumluluk bilinci aşıladığını, bu yüzden de başarılı oldukça onların özgüvenlerinin yükseldiğini, bu durumun 
öğrencilerini dijital alanlar gibi kendilerini ifade edebilecekleri ortamlarda daha çok yer almaya ve sorumluluk üstlenmeye istekli hale getirdiğini belirtmiştir. Bir katılımcı ise kendi sınıflarında yapılandırmacı yaklaşımın dijital yetkinliği artırmaya \%40 etkisi olduğunu, o kesimin de zaten sorumluluk alan ve proje çalışmalarına ilgi duyan öğrencilerden oluştuğunu belirtmiştir. Yani öğretmenin gözlemlerine göre yapılandırmacı yaklaşım kendi sınıfındaki öğrencilerinin \%60'ına fark edilir düzeyde bir katkı sağlamamıştır. Bu konuyla ilgili öğretmen görüşleri şu şekildedir:

Ö2 kodlu katılımcı: "Teknoloji çağındayız elbette. Öğrenciler dijital konularda, teknoloji ile ilgili konularda bizim gibi meslekte uzun yıllar geçiren yaş gereği 50-60 yaş civarındaki kişilere göre dünyayı daha farklı bir bakış açısılla algılıyor. Onlar teknolojinin içinde doğan çocuklar, bu yüzden daha sorgulayıcılar. Bu yüzden gelişmelere açık olduklarını düşünüyorum. Öğrenciler bilgiyi yapılandırırken teknolojinin faydası oluyor."

Ö5 kodlu katılımcı ise: "Öğrencilerin hepsine bir katkısı olduğunu düşünmüyorum. Sadece yapmak isteyen azimli ve katılımcı ögrencilerimize etkili olduğunu düşünüyorum. \%40'ık kesim zaten bu işi alıp götürüyor, projelerini sunarken onlara müdahale bile etmemizi istemiyorlar. Bir öğretmen gibi çok güzel anlatanlar ve istekli olanlar var ama bazı öğrencilerde hiçbir şekilde bunu göremiyoruz."

Tablo 6.

Türkçe Çalışma Kitaplarındaki Etkinliklerin Dijital Yetkinlikle Ilgili Kazanımları Yansıtabilmesine Yönelik Ögrretmen Görüşleri

\begin{tabular}{lc}
\hline Kodlar & $(\mathrm{f})$ \\
\hline Dijital ortamın sağlanamaması & 4 \\
EBA'yı kullanılmasını isteyen öğrenciler & 4 \\
Animasyonlar sunulmalı & 2 \\
Etkinlikler kısa ve teknolojiye uygun değil & 2 \\
Görsellik sağlanmalı & 2 \\
Kısa filmlerin oluşturulmalı & 2 \\
Kitap içerikleri & 1 \\
Hatalı sorular & 1 \\
İçeriğe ulaşma sıkıntısı & 1 \\
Görsel-uzamsal zekâya hitap etmeli & 1 \\
Dijital ortamlarda tamamlayıcı etkinlikler & 1 \\
\hline
\end{tabular}

Öğretmenler, Türkçe dersi çalışma kitaplarında ve EBA'nın içeriğinde dijital ortamın sağlanamadığını; öğrencilerin dijital ortam kullanımı, özellikle EBA'nın kullanımı konusunda istekli olduklarını; dinleme metinleri için animasyonların olmasının öğrencilerin ilgi ve isteğini arttıracağını, kitaplardaki etkinliklerin öğrencileri teknolojiye yönlendirmediğini, etkinliklere görsellik sağlamak için film vb. linklerin etkinliklere eklenmesinin gerektiğini, kitaplardaki konularla ilgili kısa filmlerin oluşturulması gerektiğini, özellikle 6. sınıf Türkçe ders kitaplarının teknoloji yönünden kötü olduğunu, $E B A^{\prime} d a$ hatalı soruların çok fazla olduğunu, çalışma kitaplarının yönlendirdiği içeriklerin bulunamadığını, görsel zekâya yönelik bulmacaların ve öğrencinin tamamlayabileceği dijital etkinliklerin olması gerektiğini belirtmişlerdir. Bu konu ile ilgili öğretmen görüşleri şu şekildedir:

Ö2 kodlu katılımcı: "Kitaptaki etkinlikleri yeterli bulmuyorum. Etkinlikler çok kısa ve yavan geliyor bana. Çocuklar internete ve teknolojiye meraklı olduğu için bizim de derste kullanmamızı talep ediyorlar. Bunlara yönelik etkinlikler olsa daha verimli çalışmalar yapılabilir diye düşünüyorum."

Ö7 kodlu katılımcı: "Bu çağda ister istemez etkinliklerin içine teknolojinin de konulması gerekiyor. Kitabı ben hazırlıyor olsaydım bizzat çocuğun yaparak yaşayarak göreceği görsel uzamsal zekâya hitap eden bulmacalar olabilirdi, drama canlandırma etkinlikleri dijital ortamda bir dramanın yarısını görüp sonrasını öğrenci tamamlayabilirdi misal ya da onun sonunu görüp başını tahmin edebilirdi filan. Bu gibi dijital unsurları kullandığın zaman öğrenci farklı girişim farklı bakış açıları geliştirebiliyor diye düşünüyorum."

Ö4 kodlu katılımcı: "Konuyla ilgili bir görsellik sağlamak amacıyla dese ki şu kitabı açın şu kaynağı açın ordan izleyin filan daha fazla ilgi çeker. Kitapları ben hazırlıyor olsaydım mesela kısa 
filmlere daha çok yer verirdim. Çünkü her konuyla ilgili yabancı kaynaklardan kısa filmler var mesela farklııklarla ilgili bir konuysa en sevdiğim kısa film Kara Bulut'un Hikâyesi. Bu olabilir ya da engellilerle ilgili çok fazla kısa film var keşke oraya bağlantısı verilse biz onu izlesek öğrenciler de onu izlese ya da ödev olarak versek bunu izleyin ardından yorumlayın gibi" diyerek yapılabileceğini düşündüğü çeşitli etkinlik fikirlerini gündeme getirmiştir.

Ö5 kodlu katılımcı ise: "8. sınıf kitabı dijital etkinlik olarak Kaşağı metni ile tiyatro versiyonunu karşılaştırmamızı istedi fakat o tiyatroyu ben ve öğretmen arkadaşlarım bulamadık, EBA'da yok. Dijital ortamda yapılması istenen etkinlikler bir ders saatinden fazla ama biz indiremiyoruz metni. EBA verdiği etkinliğe katkı sağlayacak dijital ortamı sağlayamıyor." diyerek çalışma kitapları ve EBA'nın ortaklığı ile yürütülecek etkinliklerde yaşadığı sıkıntıları ifade etmiştir.

Ayrıca Ö5 kodlu katılımcı: Okulistik, EBA gibi uygulamalardan ödev verince öğrenciler daha iyi performans gösteriyor, bu yüzden EBA'yı daha sık kullanmamı istiyorlar." diyerek öğrencilerin de öğretmeni EBA'ya yönlendirdiğini ifade etti.

Tablo 7.

Öğrencilerin Blog, E-Posta Gibi Dijital Okuryazarlık Becerisi Gerektiren Metin Türleriyle Ilgili Tutumuna Yönelik Öğretmen Görüşleri

\begin{tabular}{lc}
\hline Kodlar & $(\mathrm{f})$ \\
\hline Kuralına uygun yazmıyorlar. & 3 \\
Doldurmakta zorlanıyorlar. & 1 \\
Sosyal medyada yorumları & 1 \\
Dijital ortamda kendilerini ifade ederken zorlanmama & 1 \\
Şikayet e-postası yazabileceklerini düşünmeme & 1 \\
Teorik ve Pratik & 1 \\
\hline
\end{tabular}

Tablo incelendiğinde öğrencilerin dijital ortamlarda hazırlanan metinleri kuralına uygun yazmadıkları ve birtakım teknik hatalar yaptıkları görüşüne sahip öğretmen sayısının daha fazla olduğu ortaya çıkmaktadır. Sadece bir öğretmen içerik olarak zorlanmadıklarını dile getirmiş ancak o da yazının teknik boyutuyla ilgili bir yorum yapmamıştır. Birçok işin sanal ortamdan çözüldüğünü, çağın beklentisinin metinleri sanal ortama taşımayı gerekli kıldığını düşünürsek öğrencilerin bir konu hakkında şikâyet e-posta, kurumlara dilekçe yazma, sanal günlükler oluşturup blog yazarak kendilerine bir iş kolu bile oluşturabilme vb. konularda kendilerini geliştirmelerinin üzerinde durulması gereken bir konu olduğu görülmektedir. Bu hususta bazı öğretmenler, öğrencilerine hem teknik hem de içerik açısından düzgün metinler oluşturmalarını sağlayacak rehberliği uygulama çalışmaları yaptırarak sağladıklarını dile getirmişlerdir. Bu konudaki öğretmen görüşleri şu şekildedir: Ö5 kodlu katılımcı, "Dijital metinlerde öğrenciler yabancı dilden gelen kelimeleri okurken zorlanıyorlar. Ayrıca kendi metinlerini yazmak istediklerinde teknik hatalar yaparak yazma kurallarına uymuyorlar." şeklinde düşüncelerini ifade etti. Yine aynı katılımcı kitaplarda her şey hazır olduğu halde öğrencilerin örnek metinlerin boşluklarını bile doldurmakta zorlandıklarını ifade etti.

Ö7 kodlu katılımcı, "Blog yazmak bu yaş grubu için zor. Öğrenci derdini anlatacak bir e-posta yazmakta da zorlanabiliyor. Örneğin bir kurum ya da kuruluşa aldığı bir ürünle ilgili sorun yaşadığında e-posta yazmasını istedik. Bu durumu çok net anlatabileceğini düşünmüyorum. Çocuklarımızın dijital beceri algısı birlikte oluşturdukları sohbet ve oyun grupları. Ama faydalı bir blog yazarlığı, e-posta yazma becerisiyle ilgili sınıfımdan yüzde onu yüzde yirmisi bu işi, onun dışında bu konuda çok iyi olduklarını düşünmüyorum dijital okuryazarlık konusunda" diyerek görüşlerini bildirdi.

Ö3 kodlu katılımcı bu konuyla ilgili öğrencileriyle bilişim sınıfında bilgisayarlarda uygulama yaptığını belirtti ve şu görüşleri sundu: "Çok zorlanıyorlar. Evet çok zorlanıyorlar ve çoğu zaman da yanlış yazıyorlar. Yani yapamıyorlar maalesef. Ben elimden geldiğince doğrusunu göstermeye uygulamaya yaptırmaya çalışıyorum ama sadece okuldaki kısıtı imkânlarımızla olmuyor. Elimden geldiğince doğrusunu öğretmeye çalışıyorum. Göstererek uygulama yaptırıyorum." 
Tablo 8.

Bilim ve Teknoloji Temasının Dijital Yetkinlik Düzeyini Geliştirmeye Etkisiyle IIlgili Öğretmen Görüşleri

\begin{tabular}{lc}
\hline Kodlar & $(\mathrm{f})$ \\
\hline Bazı metinler farklı & 3 \\
Keşfetme & 2 \\
Metinler yüzeysel olmamalı & 1 \\
Teknoloji ile ilgili araştırma yapma & 1 \\
\hline
\end{tabular}

Öğretmenler, Bilim ve Teknolojini temasının farkındalık yarattı̆̆ını, bu alana ilgileri olan öğrencileri keşfetmelerini sağladığını, bu konudaki metinlerin yüzeysel kalabildiğini, öğrencileri teknoloji ile ilgili araştırmaya yapmaya sevk ettiğini ifade etmektedirler.

Ö2 kodlu katılımcı, Bilim ve Teknoloji temasının faydasını şu şekilde dile getiriyor: "Orada gördüğü metinler ilgisini çektiğinde öğrenciler bu alanda araştırma yapmaya istek duyuyor."

Ö4 kodlu katılımcı, "Aslında en çok kullanabilecekleri konu başlığı Bilim ve Teknoloji. Özellikle uzayla ilgili görsellerin çok fazla olması gerekiyor. Faydası tabi ki olur ama yeterince kullanılmıyor." diyerek bu temanın derslerde daha aktif kullanılması gerektiğini vurguladı.

Ö6 kodlu katılımcı, "Evet kesinlikle oluyor. Bu anlamda ilgisi olan öğrencilerin de farkına varmamızı sağlıyor." dedi. Ayrıca aynı katılımcı teknolojiye ilgi duyan, gelecekte bu konuda çalışabilecek öğrencileri keşfettiklerini ve yönlendirdiklerini söyledi.

Tablo 9.

Öğrencilerin Verilen Projelerle Ilgili Araştırma Yaparken Gerekli Bilgileri Diğerlerinden Ayırma, Kaynağı Sorgulama ve Bulguları Yorumlama Düzeyi Hakkında Öğretmen Görüşleri

\begin{tabular}{ll}
\hline Kodlar & $(\mathrm{f})$ \\
\hline İceriği sorgulamamam & 5 \\
Yararlandığı kaynağı yazamamam & 3 \\
Dönüt & 3 \\
Kitap okuma & 2 \\
Yanlış bilgiyi doğru bilgiden ayırt edememe & 1 \\
8. sınıflar daha iyi & 1 \\
\hline
\end{tabular}

Öğretmenlerin, öğrencilerin bulduğu metinleri kopyala-yapıştır olarak karşılarına getirdiklerini, öğrencilerin yararlandığı kaynakları yazamadığını, öğrencilere sık sık dönüt vererek onlara rehberlik ettiklerini; öğrencileri kitap okumaya, okudukları metni anlatmaya ve yorumlamaya teşvik ettiklerini, yanlış bilgiyi, doğru bilgiden ayırt etme konusunda yeterli olmadıklarını, neyi araştıracaklarını bilmediklerini, bazı öğrencilerin sorgulamadan site reklamlarını bile ödevlerinin içerisine koyduklarını ifade etmektedirler. Bu konuda öğretmen görüşleri şu şekildedir:

Ö3 kodlu katılımcı: "Çok yetersizler, araştırma ödevi çok veriyorum ama hangi bilgileri alıp getireceklerini bilmiyorlar, yaralandığı kaynağı yazamıyor ifade edemiyor. Bu konuda maalesef çok yetersizler ya da bulduğu metini olduğu gibi kopyalayıp yapıştırıp benim karşıma sunuyor ve kendisi ödev yaptığını zannediyor."

Ö5 kodlu katılımcı bu soruya birtakım örneklerle cevap verdi: "Ben bir araştırma ödevi vermiştim. Öğrencim konuyla ilgili internette bulduğu her şeyi sorgulamadan kopyala yapıştır yaparak almış. Hatta sitedeki reklamları bile... Onu ayırmayı bile bilmiyor. Bunu neden yazdın? diye soruyorum ama o sayfa çıktı karşıma diyor. Reklamların resimlerini bile çizmeye çalışmıs. Çocuklar benim ihtiyacım olan bilgi ne? Hangi bölümleri almalıyım? şeklinde bir sorgulamayı yapamıyor. Sınıflarımın \%60 । bunu yapamıyor. Genelde kirli bilgiyi ihtiyacımız olan bilgiden ayırt etme sorunları var. Mesela başka bir öğrencim bir yazar hakkında verdiğim araştırma ödevinde sitenin yazarın doğum tarihi ve ölüm tarihi ile ilgili yanlış bilgi verdiğini fark etmemiş bile, oysaki arada 150 yıl var. Internette yazan her şeyi incelemeden, araştırmadan alıp getiriyorlar." 
Ö7 kodlu kullanıcı ise, "Bu anlamda biraz bulguları sorgulama ve yorumlama düzeyinde yetersiz kalıyorlar bu da bence okuma konusunda çok istekli olmayan öğrencilerde daha çok oluyor. Onları kitap okumaya yönlendirmeye çalışıorum, okudukları metinleri anlatmaya, yorumlamaya onları teşvik ediyorum. Bu şekilde onları desteklemeye çalışıorum. Ama evet sorgulama ve yorumlama konusunda sıkıntı yaşayan öğrencilerimiz var. Sorularla onların sorgulamasını sağlıyorum, onlara rehberlik yapıyorum. Bu şekilde onlara farkındalık kazandırmaya çalışıyorum, aynı zamanda kitap okumaya yönlendiriyorum. Öğrenciler beni dinlerken de mutlaka soruları olduğunda sormaları gerektiğini söylüyorum. Bu şekilde etkin bir dinleyici ve etkin bir okuyucu olmalarını sağlamaya çalısılyorum."

Tablo 10.

Teknoloji, Eğitim ve Dijital Yetkinlik Konusuyla ilgili Yapılan MEB Seminerleriyle ilgili Öğretmen Görüşleri

\begin{tabular}{lc}
\hline Kodlar & $(f)$ \\
\hline Yeterli bilgi verilmiyor. & 5 \\
Çok kalabalık & 1 \\
Teknolojiyle ilgili takip ettikleri bir site yok. & 1 \\
Yeterli sayıda uzman sorunu & 1 \\
\hline
\end{tabular}

Öğretmenler, Millî Eğitim Bakanlığı'nın teknoloji, eğitim ve dijital yetkinlik konusunda yapılan seminerlerde yeterli bilgi verilmediğini, çok kalabalık olduğu için seminerlerden verim alınamadığını, teknolojiyle ilgili siteleri takip etmediklerini, seminerlerde eğitim verecek yeterli uzmanın olmadığını ifade etmektedirler. Öğretmenler, 21. yüzyıl yeterliliklerini sağlayıp öğrencilerle aktif bir ilişki kurabilmek adına, teknolojiyi eğitime transfer etmeleri gerektiğinin bilincinde ve bu konuda destek arayışında olduklarını belirtmektedirler. Millî Eğitim Bakanlığının yeterli desteği sağlaması, Türkiye Yeterlilikler Çerçevesi'nde de yer alan dijital yetkinliğin derslerde bilinçli bir şekilde kullanılması için öğretmenlerle ortak girişimlerde bulunulması bu yüzyılın eğitim anlayışına uygun bir hamle olacaktır. Bu konuyla ilgili öğretmen görüşleri şu şekildedir:

Ö2 kodlu katılımcı: "Bu konuyla ilgili bir bilgi yok hafızamda. Dijital yetkinlik becerileriyle ilgili bir seminer almadık demek ki yoksa hatırlardım."

Ö6 kodlu katılımcı, "Açıkçası seminerlerde herhangi bir bilgi edinmedim çünkü çok verimli olmuyor. Seminerler çok kalabalık ve kalabalık gruplarla da bu tarz şeyler uygulama gerektirdiği için ben kendimde var olan teknolojik bilgilerimle 10 yıldır öğretmenlik yapıyorum. Yoksa bana bir katkısı olduğunu düşünmüyorum." diyerek görüşlerini bildirdi.

Ö4 kodlu katılımcı ise, "Hiçbir şekilde böyle bilgiler edinemiyoruz. En son katıldığım bir seminerde teknoloji ile ilgili takip ettiğiniz bir site var mı? denildiğinde kimse bir şey söyleyemedi. Benim takip ettiğim bir site vardı. Adı 'Dünyahalleri.com' o da yakın zamanda kaynak bulamadığı için kapandı. $O$ siteyi derslerimde de kullanıyordum" şeklinde görüşlerini bildirdi. Ayrıca aynı katılımcı duyduğu bir uygulamayı paylaşarak seminerlerde öğretmenlere gösterilirse faydası olacağını belirtti.

Ö4 kodlu katılımcı, "E-konferans diye bir uygulama var. Mesela bilim sanat merkezindeki özel yetenekli çocukların farkındalıkları ile ilgili profesörler ya da herhangi bir okuldaki öğretmenler araştırmalarını paylaşabiliyor, biz de izliyoruz... Mesaj gönderiliyor size. Kimler açmış izlemiş bu görünüyor. Öğretmen orada bilgi paylaşımında bulunuyor, konuşurken bir yandan görseli yanda görüyorsunuz. Çok güzel bir uygulama. Hiçbir öğretmen ben de dâhil geçen seneye kadar bu uygulamayı bilmiyordum" şeklindeki ifadeleriyle bu uygulamayı detaylarıyla paylaştı.

Tablo 11.

Öğretmenlerin Derslerinde Teknolojiyi Eğitime Transfer Edebilmek İ̧̧in Yaptıkları Çalışmalara Iliş̧in Görüşleri

\begin{tabular}{ll}
\hline Kodlar & $(\mathrm{f})$ \\
\hline Teknolojik ortamlardan yararlanma & 4
\end{tabular}


Dijital ortamda anime olarak tasarlama $r$

Zamanı iyi kullanma $r$

İlginç bilgilerin olduğu web siteleri 1

Öğrenmede kalıcılık sağlama $\quad 1$

Öğretmenler, derslerinde teknolojiyi eğitime transfer edebilmek için Okulistik, EBA gibi teknolojik ortamlardan yararlandıklarını, okuttukları bir hikâyeyi dijital bir ortamda animasyon olarak tasarladıklarını, ders sonlarında ilginç bilgilerin yer aldığı web sitelerinden okumalar yaptıklarını, video etkinliklerinde zamanı iyi kullanmaya çalıştıklarını, derslerini müzikle birleştirip öğrenmede kalıcılığı sağlamayı amaçladıklarını ifade etmektedirler. MEB uygulamalarının öğretmenler tarafından test çözdürmek, konu tekrarı ve alıştırma yapılmasını sağlamak vb. için kullanıldığı görülmektedir. Bazı öğretmenler teknolojiyi eğitime transfer ederken yaratıcı ve farklı uygulamalar denediklerini belirtmiş ve süreç sonunda da bu durumun öğrenciler üzerinde verimli olduğunu, derse karşı da güdülenme sağladığını dile getirmişlerdir. Bu konudaki öğretmen görüleri şu şekildedir:

Ö6 kodlu katılımcı, "Derslerimde teknolojiyi eğitime transfer edebilmek için iki yıl önce millî eğitimin başlattığı bir projeye dâhil oldum. Farklı ders anlatma teknikleriyle ilgili bir projeydi. Ben de müzikle birleştirdim dersimi. Çocuklarda kalıı öğrenme sağladığını düşünüyorum. Dersler eğlenceli olduğunda ögrencilerin derse katılımları ve algıları daha yüksek oluyor genelde. Onlar için müzikli ders sunuları ya da müzikli hatırlatmalarla derslerimi desteklemeye çalışıyorum çünkü müziğin onları canlı tuttuğuna inanıyorum duyularına hitap ediyorum." cümleleriyle kendini ifade etti.

Ö5 kodlu katılımcı, "Ben çocukların teknolojik anlamda gelişmeleri için kısa bir hikâyenin görsellerini oluşturarak anime yaptım ve 5. sınıflarda bunu uyguladım. Çocuklar da isterse bireysel isterseler grup olarak seçtikleri bir hikâyeyi animasyonlarıyla kurguladılar. Daha sonra sınıfta sundular çok faydalı oldu. Bu çalışmaları onlardan sonra gelen sınıflara da gösterdim." diyerek yaptığı çalışmaları paylaştı.

Ayrıca Ö5 kodlu katılımcı, "Öğrencilere Okulistik, EBA gibi uygulamalardan görseller açıp oradaki videoları, çalışma kâğıtlarını gösterip biz de bunları hazırlayabiliriz diyorum" sözleriyle bu teknolojik ortamlardan yararlandığını dile getirdi.

Ö2 kodlu katılımcı: "Ben EBA'yı test çözdürüp uygulama yaptırmak için kullanıyorum."

Tablo 12.

Öğretmenlerin Dijital Yetkinlik Kavramıyla ilgili Görüşleri

\begin{tabular}{lc}
\hline Kodlar & (f) \\
\hline Teknolojiyi hayata olumlu yansıtmak, zararlarıyla ilgili bilinçli olmak & 3 \\
Dijital araçları kullanabilmek & 2 \\
Sunum hazırlayabilmek & 1 \\
Sosyal medya ile ilgili her şey & 1 \\
\hline
\end{tabular}

Tablo incelendiğinde bazı öğretmenlerin dijital yetkinlik kavramını bilgisayar, telefon vb. araçları kullanabilmek olarak sınırlandırdığı dijital becerilerin 21. yüzyıl ihtiyacı olarak bilgiyi yorumlama, sorgulama kendini ifade etme yaratıcılık ve üstbilişi geliştirme potansiyeline faydalarına değinmedikleri görülmüştür. Buradan yola çıkarak öğretmenlerin de bu yetkinlik ile ilgili bakış açılarını geliştirmeleri ve daha çok araştırmalarının gerekli olduğu kanısına varılabilir. Ayrıca öğretmenler teknolojinin olumlu etkileri kadar olumsuz etkileri de olduğunun bilincindedir ve teknolojiyi eğitim alanına transfer ederken zararları konusunda bilinçli davranarak dikkatli hareket edildiğinde fayda sağlayacağı görüşünde birleşmektedir. Öğretmenler, dijital yetkinliği seviyelerine uygun bir teknik bilgiyle sunum hazırlayabilme, sosyal medya ile ilgili her şey olarak da nitelendirmektedir. Bu konu hakkındaki öğretmen görüşleri şu şekildedir:

Ö7 kodlu katılımcı: "Teknoloji, teknolojinin getirdiği ürünler bunları kullanmak bunların hayata olumlu yansıtmak bunların zararlarının gerekirse farkına varmak. Her şeyin olduğu gibi bunların da zararları olabilir. Bu süreçte çağa ayak uydurmak gerekiyor çünkü artık dijital çağ diyoruz, her şey dijital 
diyoruz. Belki biz ögretmenlerin bile gelip okula ders anlatma durumu ortadan kalkacak. Dolayısıla gelişmeler, çağ ilerleyen teknoloji geliyor aklıma."

Ö3 kodlu katılımcı: "Şu an etrafımız dijital araçlarla çevrili ama bunu doğru kullanabilmeyi maalesef çoğu kişi bilmiyor. Yani sadece dijital deyince insanların aklına sosyal medyayı kullanmak, whatsapp, youtube vb.ni kullanmak geliyor o kadar. Bu durumda yarardan çok zarar getirebiliyor. Bilinçli olmak gerek ama dijital aracı doğru kullanmak konusunda yetersiz çoğu kişi."

\section{Tartışma, Sonuç ve Öneriler}

Dünyada ve Türkiye'de devam eden COViD 19 salgını süresince araştıran, düşünen, üreten bireyin yanı sıra dijital yetkinliğe sahip bireylerin önemi ortaya çıkmıştır. Bu araştırmada Türkçe Eğitiminde dijital yetkinlik kavramı farklı değişkenler açısından incelenmiştir. Özellikle öğrencilerin okula gidememesi ve derslerin uzaktan yapılaması sürecinde; teknolojik donanım eksikliği, içerik eksikliği ve bireylerin dijital yetkinlik eksikliği ön plana çıkmıştır.

Araştırmada okullarda FATiH projesinden dolayı etkileşimli tahtaların yeteri kadar bulunduğu, ama bilgisayarların intiyacı karşılayacak düzeyde ve dijital çağa uygun olmadığı görülmüştür. Okul binalarının özel bir teknolojik alan oluşturmak için yetersiz olduğu, etkileşimli tahtaları kullanan öğretmenlerin bu konuda yetkin olmadıkları için etkileşimli tahta kullanımının öğretimi aksattığı, okullardaki internet bağlantısının yetersiz olduğu, sınırlamalardan dolayı dersle ilgili bazı içeriklere ulaşılamadığı görülmüştür. Bu araştırmanın sonuçlarına benzer bir şekilde Korkmaz (2017), okullarda internet ve bilgisayarın yetersiz olduğunu tespit etmiştir. Teknolojinin hızla ilerlemesiyle beraber okullardaki bilgisayarlar teknolojiye yetişememektedir. Türkiye, genç bir nüfusa sahip olduğu için sürekli yeni okul binası ihtiyacı doğmakta, bazı okulların teknolojik donanımlarında istenilen seviyeye ulaşılamamıştır. Öğrencilerin okula bağlı internet adresinden uygunsuz sitelere girmemeleri için okul internetine kısıtlamalar getirilmekte, bu kısıtlamalar okuldaki interneti yavaşlatmaktadır.

Araştırmaya katılan öğretmenler, öğrencilerin proje merkezli değil de sınav merkezli yetiştiği, bu yüzden teknolojik araçlara yönelmede problem yaşandığını ifade etmişlerdir. Güncellenen öğretim programlarıyla dil bilgisi konularının sadeleştiği, anlatım bozuklukları ve fiillerde çatı konusunun basit düzeyde kaldığı; anlama becerisi, yorumlama, karşılaştırma becerilerinin programda ön plana çıktığı, EBA sayesinde öğrencilerin işitsel ve görsel zekâlarına da hitap edildiği görülmüştür. EBA'yla ilgili yapılan araştırmalarda (Altın ve Kalelioğlu, 2015; Saygılı ve Kana, 2016; Tüysüz ve Çümen, 2016; Bahçeci ve Efe, 2018) öğrencilerin ve öğretmenlerin EBA'yı az kullandıkları (Bahçeci, Türel, Demirli ve Dokumacı, 2016; Gürfidan ve Koç, 2016; Türker ve Güven, 2016) görülmüştür. Yapılan bu araştırmalara paralel olarak araştırmada öğrencilerin öğretmenleri EBA'dan ders işlenmesi için zorladıkları, kitaplarda ve EBA'nın içeriğinde verilen etkinliklere katkı sağlayacak dijital ortamın sağlanamadığı, dinleme etkinlikleri için animasyonların kullanılması gerektiği, kitaplardaki etkinliklerin öğrencileri teknolojiye yönlendirmediği, çalışma kitaplarında görselliğin eksik olduğu, kitaplarda ve EBA'da hatalı soruların olduğu, içerik eksikliği yaşandığı, dijital ortamlara yönelik etkinliklerin kiataplarda ve EBA'da arttırılması gerektiği görülmüştür. Demir, Özdinç ve Ünal'ın (2018) yaptığı araştırmada evinde internet erişimi ve bilgisayarı olan öğrencilerin EBA'yı kullanabildikleri, EBA'yı daha çok eğitici oyunlar oynamak, eğlence amaçılı videolar izlemek, ödevlerini yapmak ve sınavlara hazırlanmak amacıyla kullandıklarını tespit emiştir. COViD 19 salgınıyla birlikte EBA'dan uzaktan eğitim verilmeye başlanmış, EBA TV açılmış ve öğrencilere televizyon üzerinden dersler verilmeye başlanmıştır. EBA kullanan öğretmenlere ek puan verilmeye başlanınca öğretmenlerin EBA'yı etkili bir şekilde kullanmaya başladıkları; öğrencilerin de EBA'daki dersleri takip etmeye başladıkları görülmüştür. Öğretmenlerin derslerde Okulistik, EBA gibi teknolojik ortamlardan yararlandığı, dijital ortamlarda anime tasarımlar yaptıkları, web sitelerinden okumalar yaptıkları, derslerde kalıcılı̆ı arttırma için derslerini müzikle birleştirdikleri, Wattpad vb. uygulamalardaki okumaların denetlenmediği için faydasından çok zararı olduğunu düşündükleri görülmüştür.

Araştırmaya katılan öğretmenlerin ders ve çalışma kitaplarında dijital yetkinlikleri sezdirecek metinlere rastladığı ama bu metinleri daha işlemedikleri görülmüştür. Maden, Maden ve Banaz (2018) araştırmalarında Türkçe ders kitaplarında yer alan metinlerin ve etkinliklerin hazırlanmasında teknolojinin ve dijital okuryazarlık olgusunun daha fazla önemsenmesine ihtiyaç olduğunu 
belirtmişlerdir. Dolayısıyla Türkçe ders kitaplarında yer alan metinler öğrencilerde dijital yetkinlik konusunda hem farkındalık oluşmasını sağlamalı hem de teknolojinin değişimine uygun metinler ders kitaplarında yer almalıdır.

Avrupa'da pek çok ülkede proje hazırlama, öğrenme-öğretme, mesleki gelişim vb. öğretim faaliyetleri için yetkinlik seviyesini belirlemek amacıyla Avrupa Komisyonu'nun oluşturduğu Dijital Yetkinlik Çerçevesi kullanılmaktadır (Balula, 2016, s. 281). Bu araştırmada yapılandırmacı yaklaşımda öğrencilerin araştırarak öğrenmesinin öğrencilerin özgüvenini arttırdığı için, bu yaklaşımın öğrencilerin doğasına uygun olduğu, bu yaklaşım bağlamında kullanılan projeleri ödev olarak öğrenciler uyguladığında dijital yetkinliklerinin geliştiği, sunum yapmaya istekli çocuklarda etkili olduğu görülmüştür. Öğrencilerin proje ödevlerini yaparken dijital yetkinlik becerilerini geliştirdiği düşünüldüğünde Avrupa Komisyonu'nun oluşturduğu Dijital Yetkinlik Çerçevesi'nin Türkiye'de de uygulanması dijital yetkinlik becerilerini geliştirmek için önemli olacaktır.

Yapılan araştırmalarda teknolojik araçların öğrencilerin akıcı okuma ve anlama becerilerini geliştirdiği tespit edilmiştir (Ulu ve Başaran, 2013; Çayır ve Ulusoy, 2014; Değirmenci, 2014; Kaman ve Ertem, 2018, Soydaş ve Ertem, 2019). Araştırmaya katılan öğretmenler, öğrencilerin blog, e-posta gibi dijital okuryazarlık becerisi gerektiren metin türlerini kuralına uygun yazamadıklarını, kitaptaki etkinlikleri yapmakta zorlandıklarını belirtmişlerdir. Öğrencilerin dijital okuma becerilerini geliştirmeleri, dijital okuryazarlık becerilerinin de gelişmesini sağlayacaktır. Sosyal medyayla ilgili yapılan araştırmalarda (Filiz, Erol, Dönmez ve Kurt, 2014; Akın, 2017; Çömlekçi ve Başol, 2019) lise öğrencilerinin sosyal medya kullanım amaçları ile sosyal medya bağımlılığı arasında pozitif bir ilişki olduğu görülmüştür. Öğrencilere liseye gelinceye kadar ortaokulda sosyal medyayı doğru amaçlar için kullanması gerektiği konusunda rehberlik edilmelidir. Araştırmada öğretmenler, öğrencilerinin sosyal medyadaki yorumlarının çok kötü olduğunu, kendilerini sosyal medyada ifade ederken zorlanmadıklarını ama ihtiyaçlarını giderecek olan e-posta vb. dijital ortamlarda yazamayacaklarını düşündüklerini ifade etmektedirler. Öğrencilerin kendilerini sosyal medyada ifade edecek kadar özyeterli ama intiyaçları konusunda yetersiz oldukları ve sosyal medya yorumlarının çok kötü olduğu öğretmenler tarafından vurgulanmıştır. Demir (2016) sosyal medya kullanımının aile içi iletişimi olumsuz etkilediğini, Ekşi ve Ümmet (2013) de iletişim problemleri yaşayan bireyin içine kapandığını ve sanal internet dünyasına yöneldiğini ifade etmektedir. Bu araştırmada da öğretmenler, öğrencilerin sadece sosyal medyaya odaklandığını, dijital yazma becerilerini sadece yorum yapmakta kullandıklarını ifade etmektedir.

Araştırmada ders kitaplarında yer alan Bilim ve teknoloji temasının öğrencilerde farkındalık yarattı̆̆ı, bu alana ilgileri olan öğrencileri öğretmenlerin keşfetmelerini sağladığı, bazı metinlerin yüzeysel kaldığı, öğrencileri araştırma yapmaya sürüklediği ifade edilmiştir. Maden, Maden ve Banaz (2018) araştırmalarında Bilim ve Teknoloji temasında dijital okuryazarlıkla ilgili olarak sözcüklerden en fazla teknolojinin geçtiğini, bunun yanı sıra internet, medya, grafik ve televizyon gibi teknolojik terimlerin de bu temada yer aldığını tespit etmişlerdir. Dijital yetkinlikle ilgili kavramların metinlerde az kullanıldığını tespit etmişlerdir, bu araştırmanın sonuçları da bu bulguyu desteklemektedir.

Araştırmada, Milli Eğitim Bakanlığı'nın teknoloji, eğitim ve dijital yetkinlik konusunda düzenlediği seminerlerde bu konularda yeterli bilginin verilmediği, bu konuda yeterli uzmanın olmadığı, kalabalık olduğu için seminerlerden verim alınamadığı, öğretmenlerin teknolojiyle ilgili siteleri takip etmediği görülmüştür. Yapılan araştırmalarda dijital yetkinlik kavramı önceki dijital yeterlik kavramıyla açıklanmaya çalışılmış, insan odaklı bakış açısının etkisiyle dijital yetkinlik kavramı ortaya çıkmıştır (Cartelli, 2012; Gallardo-Echenique, de Oliveira, Marqués-Molias ve Esteve-Mon, 2015; Ilomäki, Paavola, Kantosalo ve Lakkala, 2016; Erişen, Gürültü ve Bildik, 2018). Öğretmenler tarafından dijital yetkinlik; öğrencilerin internet ve iletişim becerilerine sahip olunması olarak ifade edilmiştir (Erişen, Gürültü ve Bildik, 2018). Araştırmada öğretmenler dijital yetkinlik deyince akıllı tahta, bilgisayar, telefon, kamera vb. araçları kullanabilmeyi, sosyal medyayla ilgili her şeyi, öğrencilerin seviyelerine uygun bir teknik bilgiyle sunum hazırlayabilmeyi, teknolojiyi hayata olumlu yansıtabilmeyi anlamaktadırlar. Yani öğretmenlerin teknolojik donanım ve sosyal medyayı da dijital yetkinliğin içerisine katmış oldukları görülmektedir. Cho ve Lee (2011), internetin herkese açık şekilde ve herhangi bir denetim olmadan yanlış, uygunsuz, istenmedik bilgileri de içerecek şekilde 
genişlemesinin bilgi kirliliğinin ortaya çıkmasına neden olduğunu belirtmektedir. Araştırmada, öğrencilerin kaynak yazmakta zorlandığı, internette bulduğu bilgileri sorgulamadığı, öğretmenlerin bu süreçte onlara rehberlik yaptığı, öğretmenlerin de bazen öğrencileri gibi doğru bilgiyle yanlış bilgiyi ayırt edemediği görülmüştür. Dolayısıyla öğrencilere internetteki bilgileri nasıl ayırt edebileceği konusunda rehberlik edilmeli, aile ve okul tarafından öğrenciler bu konuda denetlenmeli ve uyarılmalıdır.

Scherer, Siddiq ve Teo (2015), 21. yüzyıldaki en temel hedefin öğrencileri dijital yetkinlik açısından yetiştirmek olduğunu ifade etmişlerdir. Bu araştırmanın sonuçları incelendiğinde öğretmenlerin, öğrencilerin, öğretim programlarının ve ders kitaplarının dijital yetkinlikler açısından geliştirilmesi gerektiği sonucuna ulaşılmıştır. Öğretmen ve öğrencileri bu alanda geliştirmek için okullardaki teknolojik donanımlar üst seviyeye çıkarılmalı; öğrencilerin dijital yetkinlik becerilerini geliştirmek için ders kitaplarının ve öğrencilerin kullandıkları diğer materyallerin bu yetkinliği kapsayan metinlerden oluşmasına dikkat edilmeli; okullarda yazılım, akademik yazma ile ilgili bilgiler ortaokul seviyesinden itibaren verilmeye başlanmalıdır.

Araştırmanın sonuçları doğrultusunda şu öneriler geliştirilmiştir: Teknolojik boyutu olan projelerin sayısı artmalı, EBAdaki içeriklere ulaşırken öğrenciler ve eğitimciler sorun yaşamamalı ve bu içeriklerin öğrenciyi aktif kılma düzeyi güncellemelerle birlikte üst düzeye ulaşmalıdır. Okuduğunu anlayan, yorumlayabilen, kendi bilgisini üretip hayal gücüyle pekiştiren bireyler kaliteli içerikler yazarak geleceğe yön verebilecektir. Bu bireyleri yetiştirebilmek dijital yerli olarak tanımladığımız genç kuşağın varlı̆̆ı ile bütünleştirdiği teknolojiyi bilinçli kullanmasını sağlayarak onlara içeriği zengin e-öğrenmeler ve öğretmen rehberliği sunarak mümkün olabilir.

\section{Kaynaklar}

Akar, H. (2016). Durum çalışması. A. Saban ve A. Ersoy (Ed.). Eğitimde nitel araştırma yöntemleri içinde (111-148). Ankara: Anı Yayıncılık.

Akın, M. (2017). A research on the impacts of the young people's Internet addiction levels and their social media preferences. International Review of Management and Marketing, 7(2), 256-262

Altın, H. M. ve Kalelioğlu, F. (2015). FATiH projesi ile ilgili öğrenci ve öğretmen görüşleri. Başkent University Journal of Education, 2(1), 89-105.

Arslan, H. ve Kuzu, A. (2019). EBA Ders modülünün ve sınıf yazılımının ters yüz sınıf modelinde uygulanabilirliğine yönelik öğretmen görüşleri. Bolu Abant izzet Baysal Üniversitesi Eğitim Fakültesi Dergisi, 19(1), 20-36. https://doi.org/10.17240/aibuefd.2019.19.43815-538301

Bahçeci, F., Türel, Y.K., Demirli, C. ve Dokumacı, O. (2016). Liselerde görev yapan branş öğretmenlerinin Eğitim Bilişim Ağı (EBA) kullanım tercihleri ve yeterlik algısı. $X$. International Computer and Instructional Technologies Symposium. Recep Tayyip Erdoğan Üniversitesi, Rize.

Bahçeci, F. ve Efe, B. (2018). Lise öğrencilerinin eğitim bilişim ağı (eba) sitesine yönelik görüşlerinin değerlendirilmesi. Kuramsal Eğitimbilim Dergisi, 11(4), 676-692. DOI number: http://dx.doi.org/10.30831/akukeg.387055

Balula, A. (2016). The use of DigComp in teaching and learning strategies - a roadmap towards inclusion. Proceedings of the 7th International Conference on Software Development and Technologies for Enhancing Accessibility and Fighting Info-exclusion, 275-282.

Bilgiç, H. G., Duman, D., Seferoğlu, S. S. (2011). Dijital yerlilerin özellikleri ve çevrim içi ortamların tasarlanmasındaki etkileri. Akademik Bilişim'11 - XIII. Akademik Bilişim Konferansı Bildirileri. 2-4 Şubat 2011 İnönü Üniversitesi, Malatya.

Borich, G. D. (2017). Etkili öğretim yöntemleri (M. B. Acat, Çev.). Ankara: Nobel Yayıncılık.

Cartelli, A. (2012). A framewrok for digital competence assessment. A. Cartelli (Ed.), In Future trends and future practices for digital literacy and competence (s. 47-63). Hershey: IGI Global.

Cho, D. J. and Lee, J. (2011). Fighting against "infollution" that contaminates our children's minds and their thoughts. http://www.unescobkk.org/education/ict/online-resources/databases/ict-ineducation-database/item/article/fighting-against-infollution-that-contaminates-ourchildrens-minds-and-their-thoughts/. Erişim Tarihi: 15.03.2020. 
Creswell, J. W. (2013). Araştırma deseni: Nitel, nicel ve karma yöntem yaklaşımları (Çev. Ed: S. B. Demir). İstanbul: Eğiten Kitap.

Çayır, A. ve Ulusoy, M. (2014). Akıcılığı geliştirme programının ilkokul ikinci sınıf öğrencilerinin okuma ve anlama becerileri üzerindeki etkisi. Cumhuriyet International Journal of Education, 3(2), 26-43.

Çömlekçi, M. F. ve Başol, O. (2019). Gençlerin sosyal medya kullanım amaçları ile sosyal medya bağımlılığı ilişkisinin incelenmesi. Celal Bayar Üniversitesi Sosyal Bilimler Dergisi, 17(4), 173188.

Değirmenci, H. (2014). Eğitim yazııımının birinci sını öğrencilerinin okuma becerileri üzerindeki etkisi: Morpa Kampüs uygulaması (Yayımlanmamış Doktora tezi). Gazi Üniversitesi Eğitim Bilimleri Enstitüsü Illköğretim Anabilim Dalı, Ankara.

Demir, Ü. (2016). Sosyal medya kullanımı ve aile iletişimi: Çanakkale'deki lise öğrencileri üzerine bir araştırma. Selçuk Üniversitesi iletişim Fakültesi Dergisi, 9(2), 27-50.

Demir, D., Özdinç, F. ve Ünal, E. (2018). Eğitim bilişim ağı (EBA) portalına katılımın incelenmesi. Erzincan Üniversitesi Eğitim Fakültesi Dergisi, 20(2), 407-422. Doi numarası: 10.17556/erziefd.402125

Doğru, B. N., Meçik, O. (2018). Türkiye'de endüstri 4.0'ın işgücü piyasasina etkileri: Firma beklentileri. SDÜ IiBF Dergisi, (23),1581-1606.

Ekşi, F. ve Ümmet, D. (2013). Bir kişilerarası iletişim problemi olarak internet bağımlılığı ve siber zorbalık: psikolojik danışma açısından değerlendirilmesi. Değerler Eğitimi Dergisi, 11(25), 91115. Retrieved from http://dergipark.org.tr/ded/issue/29175/312422. Erişim Tarihi: 04.05.2020

Erdem, M. ve Akkoyunlu, B. (2002). Bilgi okuryazarlığı becerileri ve bu becerilerin öğrencilere kazandırılması için düzenlenecek öğrenme ortamlarının özellikleri, Journal of Qafqaz University, $125-132$. file://C:/Users/COMU/Downloads/Bilgiokuryazarlbecerilerivebubecerilerinrencilerekazandrl masiindzenlenecekrenmeortamlarnnzellikleri.pdf Erişim Tarihi: 04.04.2020

Erişen, Y., Gürültü, E. ve Bildik, C. (2018). Evaluation of digital competence by information technology teachers in Turkey in the context of 21st century skills and the quality framework of ministry of education. European Journal of Education Studies, 4(7). DOI: 10.5281/zenodo.1254623

Eryılmaz, S. ve Uluyol, Ç. (2015). 21. Yüzyıl becerileri ışığında FATiH projesi değerlendirmesi. Gazi Üniversitesi Gazi Eğitim Fakültesi Dergisi, 35(2), 209-229. Retrieved from http://www.gefad.gazi.edu.tr/tr/issue/6772/91207. Erişim Tarihi: 09.04.2020

Filiz, O., Erol, O., Dönmez, F. İ. ve Kurt, A. A. (2014). BÖTE bölümü öğrencilerinin sosyal ağ siteleri kullanım amaçları ile internet bağımlılıkları arasındaki ilişkinin incelenmesi. Journal of Instructional Technologies \& Teacher Education, 3(2), 17-28.

Fraillon, J., Ainley, J., Schulz, W., Friedman, T. and Gebhardt, E. (2014). Preparing for life in a digital age - The IEA international computer and information literacy study international report. Springer International Publishing.

Fundalina (2020). 2020 Yılı Global Dijital Raporu. Erşim Adresi: https://www.fundalina.com/2020-yiliglobal-dijital-raporu/ Erişim Tarihi: 16.04.2020.

Gallardo-Echenique, E. E., de Oliveira, J. M., Marqués-Molias, L. and Esteve-Mon, F. (2015). Digital competence in the knowledge society. MERLOT Journal of Online Learning and Teaching, 11(1), 1-16.

Gürfidan, H., \& Koç, M. (2016) Eğitim Bilişim Ağı (EBA) kullanımının öğretmen görüşleri doğrultusunda değerlendirilmesi. $X$. International Computer and Instructional Technologies Symposium. Recep Tayyip Erdoğan Üniversitesi, Rize.

Ilomäki, L., Paavola, S., Kantosalo, A. and Lakkala, M. (2016). Digital Competence-an emergent boundary concept for policy and educational research. Educ. Inf. Technol (21), 655679.https://www.myk.gov.tr/index.php/tr/turkiye-yeterlilikler-cercevesi. Erişim tarihi: 10.03.2020 
Kaman, S. ve Ertem, i. S. (2018). The effect of digital texts on primary students' comprehension, fluency, and attitude. Eurasian Journal of Educational Research, 76, 147-164.

Kazu ve Erten (2014). Öğretmen adaylarının sayısal yetkinlik düzeyleri. Bartın Üniversitesi Eğitim Fakültesi Dergisi, 3(2), s. 132 - 152. Doi: 10.14686/BUEFAD.201428175

Korkmaz, F (2017). Din dersi öğretmenlerinin bir öğretim materyali olarak filmleri kullanma durumları. Bilimname XXXIII(1), 35-66. http://dx.doi.org/10.21646/bilimname.2017.17

Kozikoğlu, I. ve Altunova, N. (2008). Öğretmen adaylarının 21. yüzyıl becerilerine ilişkin öz-yeterlik algılarının yaşam boyu öğrenme eğilimlerini yordama gücü. Yükseköğretim ve Bilim Dergisi, 8(3), 522-531.doi: 10.5961/jhes.2018.293

Kurudayıoğlu, M. ve Soysal, T. (2020). 2018 Türkçe dersi öğretim programı'ıı dijital yetkinlik bakımından incelenmesi. Mehmet Akif Ersoy Üniversitesi Eğitim Fakültesi Dergisi, 12(54), 184-199 . Retrieved from https://dergipark.org.tr/tr/pub/maeuefd/issue/53827/658584. Erişim Tarihi: 05.06.2020.

Larraz, V. and Esteve, F. (2015). Evaluating digital competence in simulation environments. E. G. Bullen, In Teaching and learning in digital worlds, strategies and issues in higher education (s. 99-105). Tarragone: URV.

Maden, S., Maden, A. ve Banaz, E. (2018). Ortaokul 5. sınıf türkçe ders kitaplarının dijital okuryazarlık bağlamında değerlendirilmesi. Uluslararası Sosyal Araştırmalar Dergisi, 11(55), http://www.sosyalarastirmalar.com/cilt11/sayi55_pdf/5egitim/maden_sedat.pdf

Merriam, S. B. (2013). Nitel araştırma desen ve uygulama için bir rehber (Çev. Ed. Selahattin Turan). Ankara: Nobel Akademik Yayıncılık.

Miles, B. ve Huberman, M. (2015). Genişletilmiş bir kaynak kitap: Nitel veri analizi (Çev. Ed: Sadegül Akbaba Altun - Ali Ersoy). Ankara: Pegem Akademi Yayıncılık.

Saygılı, D. ve Kana, F. (2016). Ortaöğretim Türk Dili ve Edebiyatı Dersinde Eğitim Bilişim Ağı'nın kullanımına yönelik öğrenci görüşlerine yönelik bir durum çalışması. Akdeniz Eğitim Araştırmaları Dergisi, 10(20), 11-23.

Schmidt, E. and Cohen, J. (2013). The new digital age. New York: Vintagebooks.

Soydaş, B. ve Ertem, S. İ. (2019). Dijital metinleri tekrarlı okumanın ilkokul 4. sınıf öğrencilerinin akıcı okuma ve anlama becerileri üzerine etkisi. International Social Mentality and Researcher Thinkers Journal, 5(26), 1987-2005

Şişman, M. (2002). Eğitimde mükemmellik arayışı: Etkili okullar. Ankara: PegemA Yayıncılık.

Şirin, H. (2016). 21. Yüzyılda eğitim bilimlerinde yönelimler. L. Küçükahmet, (Ed.). Eğitim bilimine giriş içinde (s. 23-45). Ankara: Nobel Akademik Yayıncılık.

Türker, A., ve Güven, C. (2016). Lise öğretmenlerinin Eğitim Bilişim Ağı (EBA) projesinden yararlanma düzeyleri ve proje ile ilgili görüşleri. Eğitim ve Öğretim Araştırmaları Dergisi, 5(1), 244-254.

Tüysüz, C., ve Çümen, V. (2016). EBA Ders web sitesine ilişkin ortaokul öğrencilerinin görüşleri. Uşak University Journal of Social Sciences, 9(27), 278-296.

Ulu, M., ve Başaran, M. (2013). Video öz değerlendirme tekniğinin akıcı okuma becerisinin gelişimine etkisi. Dumlupınar Üniversitesi Sosyal Bilimler Dergisi, 38, 1-10.

Yıldırım, A. ve Şimşek, H. (2018). Sosyal bilimlerde nitel araştırma yöntemleri. Ankara: Seçkin Yayıncilık.

\section{Introduction}

\section{Extended Abstract}

In the 21st century, individuals need self-improvement in order to progress. While shaping these needs, the needs of the century should be taken into consideration and the education system should meet the needs of the century. Considering the needs of today, it is seen that it is not enough to receive and use the information directly. The ability to access information from the right sources, question the reliability of the information, make it functional by interpreting the information obtained and transfer it to daily life has gained importance (Fraillon, Ainley, Schulz, Friedman, and Gebhardt, 2014). Technology is used effectively in this century. According to the Global Digital Report of 2020 , the number of internet users has increased to 4.54 billion. There are 3.80 billion social 
media users worldwide, more than 5.19 billion people use mobile phones. The average internet user uses the internet 6 hours and 43 minutes every day (Fundalina, 2020). Considering all these data, 8 billion people in the world are expected to have internet access in 2025 and it is estimated that this number will increase exponentially (Schmidt \& Cohen, 2013, p.4). This century is called the information age, people living in this century learn information mostly from internet, computer and mobile resources. Many NGOs worldwide (European Union, ATCS, OECD) have determined the skills that individuals should have in the 21st century, taking into account their own criteria and the needs of the century. These skills are high-level skills such as critical and creative thinking, problem solving, and using technological tools (Kazikoğlu and Altunova, 2018, p.523). When the digital competence in the Turkish Curriculum is reflected in the educational environment, it will be possible to train individuals who possess 21st century skills and who are capable of making the breakthroughs required by the age and who have high interpretability. The aim of this study is to examine students' digital competence skills through the eyes of teachers who actively live in the classroom environment with children of the digital age and to reveal findings that can contribute to the field and education programs in the light of these views.

\section{Method}

In this study, a case study pattern was used to determine the digital competence skill levels of secondary school students. Digital competence, which is the subject of the research, is a current and real world context due to the worldwide outbreak of COVID 19. Since students do not go to school in this process, they enter their classes through distance education. In order for students to listen to and react to these lessons, they must have both digital tools and digital skills. The data obtained from the research were analyzed through descriptive analysis, one of the qualitative data analysis methods. In descriptive analysis, the data are interpreted according to the themes previously determined by the researcher (Yıldırım and Şimşek, 2018). The data obtained from the research were analyzed according to the themes previously determined by the researcher. In addition, in order to increase the credibility of the data obtained from the research, it was included in the study through direct transfer from the study group. The participants were given code by the researcher (Ö1, Ö2, Ö3...). Semi-structured interview form created by the researcher was used in the research. To ensure the structural validity of the research, participant diversification was made. In the research, it was paid attention that the participants who collected data were not only from one branch but also teachers with different branches, age groups and years of service. In the research, researcher diversification was made. The data obtained in the research were analyzed by different researchers to ensure that the findings and analyzes were consistent. In order to ensure the internal validity of the research, the data obtained through the excerpts of the research study group are included in the findings section. The findings of the research were generalized and external validity was provided. In order to ensure the internal reliability of the research, other researchers were provided to analyze and verify the data (Creswell, 2013; Merriam, 2013).

\section{Result and Discussion}

It has been observed that interactive boards are sufficient in schools due to the FATIH project, but computers are not at a level to meet the needs and are not suitable for the digital age. It has been observed that school buildings are insufficient to create a special technological area, teachers who use interactive boards are not competent in this regard, and the use of interactive boards is disruptive, the internet connection in schools is inadequate, and some content related to the course is not available due to limitations. It has been observed that students are trained not in the project center but in the exam center, so there is a problem in turning to the technological tools. With the updated curriculum, grammatical issues have been simplified, and narration disorders and verbs remained simple in verbs; comprehension, interpretation, and comparison skills were seen to be prominent in the program, and thanks to EBA, students' auditory and visual intelligence were also addressed. It was observed that the teachers came across texts to sense digital competencies in their textbooks and workbooks, but they did not process these texts yet. In their research, Maden, Maden 
and Banaz (2018) stated that technology and digital literacy are needed more in the preparation of texts and activities in Turkish textbooks. Therefore, the texts in the Turkish textbooks should both raise awareness about digital competence in students and texts suitable for the change of technology should be included in the textbooks. It has been stated that the science and technology theme in the textbooks creates awareness among students, enables students to discover students who are interested in this field, some texts remain superficial, and drag students to research. In their research on Maden, Maden and Banaz (2018), they found that the most technology was mentioned in terms of digital literacy in the Science and Technology theme, as well as technological terms such as internet, media, graphics and television. In the research, it was seen that in the seminars organized by the Ministry of National Education on technology, education and digital competence, sufficient information was not given on these issues, there were not enough experts on this subject, and the seminars could not be yielded because of the crowd, and teachers did not follow the technology related sites. In the researches, the concept of digital competence has been tried to be explained with the concept of previous digital competence and the concept of digital competence has emerged with the effect of a human-oriented perspective (Cartelli, 2012; Gallardo-Echenique, de Oliveira, Marqués-Molias ve Esteve-Mon, 2015; Ilomäki, Paavola, Kantosalo ve Lakkala, 2016; Erişen, Gürültü ve Bildik, 2018). 